\title{
EFFICACY OF SOME PLANT POWDERS AS COWPEA GRAIN PROTECTANT FROM INFESTATION WITH COWPEA BEETLE, CALLOSOBRUCHUS CHINENSIS L. (COLEOPTERA : BRUCHIDAE)
}

\author{
B. M. Eldefrawy \\ Economic Entomology \& Agric. Zoology Dept., Fac. Agric., Menoufia Univ., Egypt
}

Received: Feb. 14, 2017

Accepted: Mar. 1, 2017

\begin{abstract}
This work was conducted to evaluate the efficacy of seven plant powders on the biology of the cowpea beetle, Callosobruchus chinensis (L). All plant powders were tested for their repellency action and Insecticidal effect against $C$. chinensis . Regarding to the avoiding rate percentages, results indicated that one day after treatment, the highest percentage was $81.5 \%$ at banana powder, while the least one was $67.6 \%$ at fenugreek powder. The highest avoiding rates were recorded with the powders of spearmint and lemongrass resulting $61.3 \%$, while the least rates was recorded with fenugreek giving 32.5\%, 8 days after treatments. The highest decrease percentages in the number of laid eggs was recorded with the treatment of lantana at the first generation giving $61.4 \%$ decreased to $41.6,24.4 \%$ at the second and third generations, respectively. The least decrease percentages in the number of laid eggs was recorded with the treatment of orange at the third generation giving $14.4 \%$ while it was $30.6, \%$ at the first and second generations. The highest numbers of emerged adults was appeared with banana powders recording 258 , while the lowest number was occurred at lantana treatment recording 150.0 adults, in comparison with 471.7 adults in control treatment. The lowest mean numbers of emerged adults along the three generations was recorded with lantana powder, followed by lemon grass treatment. The lowest percentage of emerged females was occurred on lantana powder where the percentage of progeny was $21.3 \%, 29.3 \%$ for fenugreek, $33 \%$ for orange, $34.1 \%$ for lemongrass , $34.7 \%$ for lupine, $38.9 \%$ for banana without significant differences , in comparison with $49.5 \%$ in control. The highest relative protection percentages, along the three generations were recorded with lantana powder recording $36.1,64.7$ and $68.2 \%$ for the first , second and third generation, respectively followed by lemon grass and lupine ranging between 52.3 to $59.8 \%$.
\end{abstract}

Key words: Cowpea beetles. control, Biology, repellency action

\section{INTRODUCTION}

Stored seeds usually form a suitable environment for different insect species to exist as well as, seed stores provide a most suitable habitat for insects to breed and multiply until the food reserves are exhausted. Stored product insects are serious pests of dried, stored, durable agricultural commodities, and of many valueadded food products in the world. Food grain losses due to insect infestation during storage are amounting to $5-10 \%$ in the temperature zone and $20-30 \%$ or more in the tropical and subtropical regions particularly in developing countries
(Shivanna et al 1994, Rajendran and Sriranjini, 2008, Phillips and Throne 2010). Before the Callosobruchus maculatus larva reaches the cotyledons, it has cross the seed coat, which may represent a critical event in the infestation of non-host seeds due to the physical characteristics and toxicity of this tissue (Oliveira et al., 2001 and Ram et al 2001). The seed coat consists of several layers of specialized material cell types that provide an important interface between the embryo and external environment during embryogenesis dormancy and germination (Haughn and Chaudhury, 2005). The ability of the storage 
Bruchidae to pass through many succeeding generations on the same seeds until the food reserves are exhausted is well known and the amount of damage caused to harvested crops has been well documented (Prevetts, 1961; Kourd et al., 1971 and Bato \& Sanchez 1972).

The overall damage in leguminous seeds depends mainly on the numbers of insect species as well as the period of storage. Information concerning damage in broad, lentil, pea and cowpea seeds due to infestation with Callosobruchus maculatus and Callosobruchus chinensis are lacking.

The present work was carried out to study the efficacy of certain plant powders against the bruchid beetle Callosobruchus chinensis infesting cowpea seeds.

\section{MATERIALS AND METHODS}

This investigation was carried out to study the toxic effect of seven plant leaf powders on some biological aspects of cowpea beetle, Callosobruchus chinensis (L) at Economic Entomology \& Agric. Zoology Dept. Laboratories of the Faculty of Agriculture, Menoufia University during 2015 season:

Leaves of each plant were collected, air dried and ground to a fine powders (60 mesh). Each powder was mixed thoroughly with clean cowpea seeds at the rate of $4 \%$ (W/W).

\section{Repellency action of plant powders:}

All plant powders were tested for their repellency action against $C$. chinensis by the method of Laudnai and Swand (1954) where it was a choice test apparatus consisting of a circular foam ( $125 \mathrm{~cm}$ diameter) with eight containers, seven of them contained $50 \mathrm{~g}$ of the treated seeds with each powder and one contained $50 \mathrm{~g}$ of untreated seeds (control)

1-. Spearmint(Mentha viridis)

2- Lantana (Lantana camara)

3- Lemon grass (Cymbopogon citratus)

4- Orange (Citrus sinensis)

5- Banana (Musa paradisiaca)
6- Lupine (Lupinus albus)

7-Fenugreek (Trigonella foenum graecum)

One hundred newly emerged adults (0$24 \mathrm{~h}$ old) (50 males and 50 females) were released in the center and then covered tightly. So the insects move inside the apparatus toward the container and lay the eggs according to their choice. After 1, 2, 4 and 8 days each container was removed from the apparatus. The insects were counted and recorded, Then replaced into their positions in the apparatus. The test was repeated 3 times and kept at $30 \pm 2{ }^{\circ} \mathrm{C}$ and $75 \pm 5 \%$ R.H. Attractancy - repellency effects were measured according to Leonard and Ehrman (1976).

$\%$ Repellency $=$

No. of insects in cont - No. of insects in treat $x 100$ No. of insects in control

\section{Insecticidal effect of plant powders:}

Each powder was mixed with clean cowpea seeds at the rate of $100 \mathrm{~g}$ seeds and $10 \mathrm{~g}$ plant powder and kept in a small jar. Three replicates were made for each plant powder. C. chinensis beetles were reared on the seeds at $28 \pm 2{ }^{\circ} \mathrm{C}$ and $70 \pm 5$ $\%$ R.H. Fifteen pairs (Male + Female) of newly emerged adults were introduced into each jar with $10 \mathrm{~g}$ of each plant powder. Twenty four hours later, insects were removed and the jars containing seeds and plant powders having eggs were kept till egg hatching. All jars were kept at the same conditions till emergency of $\mathrm{Fl}$ progeny which were counted and the percentages of $\mathrm{FI}$ progeny emerged from treated and untreated seed were calculated. Three generations were reared according to the previous steps.

The laid eggs on the seeds in each container were counted, then put in a small jar and kept at the same condition $\left(28 \pm 2{ }^{\circ} \mathrm{C}\right.$ and $70 \pm 5 \%$ R.H.) till the beginning of egg hatching. All jars were kept at the same conditions till the emergence of progeny which was counted, and the percentages of emerged progeny and the reduction in 
progeny in comparison to control were estimated.

Data were analyzed by the analysis of variance (ANOVA) and means were compared by the Duncan's multiple range test. The (SPSS program version 21) was used for statistical analyses. using SPSS program. Statistical significance was established at $P \leq 0.05$ for all analyses.

Decrease and reduction percentages in females and other biological characters were computed according to (Abbott, 1925) equation. The standard errors of the means (SE) were determined. The obtained data were subjected to statistical analysis of variance (ANOVA) at $5 \%$ probability, and the measurements were separated using Duncan's Multiple Range Test (DMRT) through CoStat software program (Version 6.400). CoStat version 6.400 Copyright (C) 1998-2008 Cohort Software. 798 Lighthouse Ave. PMB 320, Monterey, CA, 93940, USA.

\section{RESULTS AND DISCUSSION}

These experiments were conducted to study the repellency effect of seven plant powders against cowpea beetle, Callosobruchus chinensis infesting stored cowpea seeds, in addition to the insecticidal effects of these powders on some biological aspects of the target beetle along three generations.

\section{1- Repellency effect of plant powders:}

Data presented in Table (1) reported that one day after treatment, the mean number of beetles in treated cowpea seeds were varied between $5.3-9.3$ individuals with significant differences (LSD5\% =1.9). The lowest mean number took place among cowpea seeds mixed with banana powder, while the highest mean number was recorded in fenugreek powder, in comparison with 28.7 beetle in control treatment.

Table (1): Response of $C$. chinensis beetles to the repellency effect of certain plant powders at $30 \pm 2{ }^{\circ} \mathrm{C}$ and $75 \pm 5 \mathrm{RH} \%$.

\begin{tabular}{|c|c|c|c|c|c|c|c|c|}
\hline \multirow[t]{3}{*}{ Plant powder } & \multicolumn{8}{|c|}{$\begin{array}{c}\text { Mean numbers of } C \text {. chinensis beetles } \\
\text { Days after treatment }\end{array}$} \\
\hline & \multicolumn{2}{|l|}{1} & \multicolumn{2}{|l|}{2} & \multicolumn{2}{|l|}{4} & \multicolumn{2}{|l|}{8} \\
\hline & $\begin{array}{l}\text { Mean } \\
\pm S . E .\end{array}$ & $A^{*} \%$ & $\begin{array}{l}\text { Mean } \\
\pm S . E .\end{array}$ & $A^{*} \%$ & $\begin{array}{l}\text { Mean } \\
\pm S . E .\end{array}$ & $A^{*} \%$ & $\begin{array}{l}\text { Mean } \\
\pm S . E .\end{array}$ & $A^{*} \%$ \\
\hline Spearmint & $6.7 \pm 0.88^{d}$ & 76.7 & $7.3 \pm 0.88^{c d}$ & 66.3 & $6.3 \pm 0.33^{d}$ & 61.3 & $6.3 \pm 0.33^{d}$ & 61.3 \\
\hline Lantana & $8.7 \pm 0.88^{b c}$ & 69.7 & $9.7 \pm 0.33^{b c}$ & 55.3 & $10.3 \pm 0.3^{b}$ & 36.8 & $10.3 \pm 0.3^{b}$ & 36.8 \\
\hline Lemon grass & $8.0 \pm 1.73^{c}$ & 72.1 & $6.3 \pm 0.33^{d}$ & 70.9 & $6.3 \pm 0.88^{d}$ & 61.3 & $6.3 \pm 0.88^{d}$ & 61.3 \\
\hline Orange & $6.3 \pm 0.33^{d}$ & 78.0 & $8.3 \pm 0.67^{c}$ & 61.8 & $9.6 \pm 0.33^{b c}$ & 41.1 & $9.6 \pm 0.33^{b c}$ & 41.1 \\
\hline Banana & $5.3 \pm 0.33^{d}$ & 81.5 & $6.7 \pm 0.33^{d}$ & 69.1 & $8.3 \pm 0.67^{c}$ & 49.0 & $8.3 \pm 0.67^{c}$ & 49.0 \\
\hline Lupine & $8.3 \pm 0.33^{b c}$ & 71.0 & $8.0 \pm 0.58^{c}$ & 63.1 & $10.3 \pm 0.9^{b}$ & 36.8 & $10.3 \pm 0.9^{b}$ & 36.8 \\
\hline Fenugreek & $9.3 \pm 0.67^{b}$ & 67.6 & $10.7 \pm 0.7^{b}$ & 46.0 & $11.0 \pm 0.6^{b}$ & 32.5 & $11.0 \pm 0.6^{b}$ & 32.5 \\
\hline Control & $28.7 \pm 1.3^{a}$ & - & $21.7 \pm 1.2^{a}$ & - & $16.3 \pm 1.2^{\mathrm{a}}$ & - & $16.3 \pm 1.2^{a}$ & - \\
\hline $\begin{array}{l}\text { F } \\
\text { L.S.D. }\end{array}$ & & & & & & & & \\
\hline
\end{tabular}

$\mathrm{A}^{*} \%$ = avoiding rate $\%$ 
Meanwhile, two days after application, the mean number of beetles was ranged between $6.3-10.7$ individuals, in comparison with 21.7 beetle in control treatment, with significant differences (LSD5\% =1.9). Four and eight days after seed treating, the mean numbers of beetles was similar and ranged between 6.3 to 11.0 insects.

Regarding to the avoiding rate percentages, results indicated that one day after treatment, the highest percentage was $81.5 \%$ at banana powder, while the least one was $67.6 \%$ at fenugreek powder. It could be observed that the avoiding rates were decreased after 4 and 8 days of treatment for all tested agents.

It could be observed that the highest avoiding rates were recorded with the powders of spearmint and lemongrass resulting $61.3 \%$, while the least rates was recorded with fenugreek giving $32.5 \%, 8$ days after treatments.

\section{2- Insecticidal effect of powders:}

Results in Table (2) show the effect of certain plant powders on the fecundity of $\mathrm{C}$. chinensis throughout three successive generations.

Table (2): Effect of certain plant powders on egg production of $C$. chinensis throughout three generation of treated cowpea seeds at $28 \pm 2{ }^{\circ} \mathrm{C}$ and $70 \pm 5 \mathrm{RH} \%$.

\begin{tabular}{|c|c|c|c|c|c|c|c|c|c|}
\hline \multirow{3}{*}{$\begin{array}{l}\text { Plant } \\
\text { powder }\end{array}$} & \multicolumn{9}{|c|}{ Number of laid eggs } \\
\hline & \multicolumn{3}{|c|}{ Generation I } & \multicolumn{3}{|c|}{ Generation II } & \multicolumn{3}{|c|}{ Generation III } \\
\hline & $\begin{array}{l}\text { Total } / 15 \\
\text { female }\end{array}$ & $\begin{array}{l}\text { mean/fem } \\
\text { ale } \pm S . E .\end{array}$ & $\begin{array}{c}\text { Dec. } \\
\%\end{array}$ & $\begin{array}{l}\text { Total } / 15 \\
\text { female }\end{array}$ & $\begin{array}{c}\text { Mean/fema } \\
\text { le } \pm S . E .\end{array}$ & $\begin{array}{c}\text { Dec. } \\
\%\end{array}$ & $\begin{array}{l}\text { Total } / 15 \\
\text { female }\end{array}$ & $\begin{array}{l}\text { Mean/fema } \\
\text { le } \pm S . E .\end{array}$ & $\begin{array}{c}\text { Dec. } \\
\%\end{array}$ \\
\hline $\begin{array}{l}\text { Spearmint } \\
\text { T test }\end{array}$ & 717 & $\begin{array}{c}47.8 \pm 0.89 \\
19.43^{\star \star}\end{array}$ & 38.3 & 768 & $\begin{array}{c}51.2 \pm 1.27 \\
11.51^{* *}\end{array}$ & 28.0 & 696 & $\begin{array}{c}46.4 \pm 0.73 \\
6.06^{\star \star}\end{array}$ & 25.5 \\
\hline $\begin{array}{l}\text { Lantana } \\
\text { T test }\end{array}$ & 441 & $\begin{array}{c}29.4 \pm 1.93 \\
11.42^{\star \star}\end{array}$ & 61.4 & 624 & $\begin{array}{c}41.6 \pm 0.80 \\
20.84\end{array}$ & 41.6 & 711 & $\begin{array}{c}47.4 \pm 1.61 \\
5.02^{\star *}\end{array}$ & 24.4 \\
\hline $\begin{array}{l}\text { Lemon } \\
\text { grass } \\
\text { T test }\end{array}$ & 680 & $\begin{array}{c}45.3 \pm 1.15 \\
16.5^{\star *}\end{array}$ & 41.5 & 659 & $\begin{array}{c}43.9 \pm 0.32 \\
22.40^{* *}\end{array}$ & 38.4 & 655 & $\begin{array}{c}43.7 \pm 0.72 \\
7.14^{\star *}\end{array}$ & 30.1 \\
\hline $\begin{array}{l}\text { Orange } \\
\text { T test }\end{array}$ & 807 & $\begin{array}{c}53.8 \pm 1.45 \\
12.461^{\star *}\end{array}$ & 30.6 & 741 & $\begin{array}{c}49.4 \pm 1.39 \\
11.96^{* *}\end{array}$ & 30.6 & 796 & $\begin{array}{c}53.06 \pm 1.04 \\
3.38^{\star}\end{array}$ & 14.4 \\
\hline $\begin{array}{l}\text { Banana } \\
\text { T test }\end{array}$ & 606 & $\begin{array}{c}40.4 \pm 1.24 \\
13.476^{\star *}\end{array}$ & 47.8 & 873 & $\begin{array}{c}58.2 \pm 1.44 \\
13.25^{\star *}\end{array}$ & 18.3 & 591 & $\begin{array}{c}39.4 \pm 0.85 \\
8.62^{* *}\end{array}$ & 36.3 \\
\hline $\begin{array}{l}\text { Lupine } \\
\text { T test }\end{array}$ & 602 & $\begin{array}{c}40.1 \pm 1.35 \\
20.38^{\star \star}\end{array}$ & 48.2 & 666 & $\begin{array}{c}44.4 \pm 1.19 \\
15.94^{* *}\end{array}$ & 37.6 & 685 & $\begin{array}{c}45.7 \pm 0.51 \\
6.48^{\star *}\end{array}$ & 26.4 \\
\hline $\begin{array}{l}\text { Fenugreek } \\
\text { T test }\end{array}$ & 692 & $\begin{array}{c}46.1 \pm 0.28 \\
24.702^{\star *}\end{array}$ & 40.5 & 894 & $\begin{array}{c}59.6 \pm 1.89 \\
5.80\end{array}$ & 16.4 & 735 & $\begin{array}{c}49.0 \pm 1.28 \\
4.74^{* *}\end{array}$ & 21.5 \\
\hline Control & 1161 & $77.4 \pm 1.24$ & - & 1068 & $71.2 \pm 1.18$ & - & 936 & $62.4 \pm 2.54$ & - \\
\hline
\end{tabular}

Dec. $\%=$ decrease percentage 


\section{- Egg deposition:}

Results in Table (2) indicated that there were significant differences in the number of laid eggs by females fed on cowpea seeds treated with different leaf powders along the three generations, where the highest numbers of eggs at the first generation were laid by females reared on coated grains with orange leaf powder reaching 53.8 eggs / female followed by those of spearmint treatment with 47.8 eggs / female and then those of fenugreek with 46.1 eggs / female, and was 45.3 eggs / female at lemon grass treatment in comparison with 77.4 egg in control treatment. The least number of eggs was obtained at the treatment of lantana giving 29.4 egg / female, respectively . At the second generation, the highest numbers of laid eggs were observed with females reared on coated grains with banana and fenugreek leaf powders reaching 58.2, 59.6 eggs / female, respectively in comparison with 71.2 eggs in control treatment.

As for the third generation, results (Table 2) indicated that the highest numbers of eggs were laid by females reared on coated grains with orange leaf powder reaching 53.06 eggs / female followed by those of fenugreek treatment with 49.0 eggs / female, in comparison with 62.4 eggs in control treatment.

Also, results in (Table 2) indicated that the highest decrease percentages in the number of laid eggs was recorded with the treatment of lantana at the first generation giving 61.4 $\%$ decreased to $41.6,24.4 \%$ at the second and third generations, respectively. The least decrease percentages in the number of laid eggs was recorded with the treatment of orange at the third generation giving $14.4 \%$ while it was $30.6, \%$ at the first and second generations .

\section{- Emerged adults:}

The obtained results in Table (3) show the number of emerged adults produced from each treatment ( 15 females) reared for three generations.
Statistical analysis of the data in Table (3) indicated that there were significant differences in the number of emerged adults among all tested materials along the three generations. As for the first generation of cowpea beetles emerged from infested grains treated with various plant powders, the highest mean numbers were observed on grains mixed with banana powder reaching 344.7 adults, while the lowest mean numbers of emerged females was $198.0,199.7$ adults occurred in lemon grass, lupine powders, in comparison with 461 adults in control treatment. In the second generation, the highest mean number of emerged adults was 281.7 on fenugreek powder, while the least mean numbers were observed on treated grains with Lantana (166.7) in comparison with 641.7 adults in control treatment. As for the third generation, the highest numbers of emerged adults was appeared with banana powders recording 258 , while the lowest number was occurred at lantana treatment recording 150.0 adults, in comparison with 471.7 adults in control treatment .

It could be concluded that, the lowest mean numbers of emerged adults along the three generations was recorded with lantana powder, followed by lemon grass treatment.

\section{- Relative protection of the plant powders:}

Data in Table ( 4 ) show that the least emerged female percentage at the first generation was recorded in the treatment of fenugreek recording $29.4 \%$ without significant differences with spearmint , lemongrass, lupine, powder, orange, in comparison with $39.7 \%$ in control treatment, while the highest percentage was observed with banana powder (42.6\%).

As for the second generation, the lowest percentage of emerged females was $26.8 \%$ for lantana powder , $29.9 \%$ for lupine powder, $30.2 \%$ for lemongrass , $30.4 \%$ for spearmint, $38.5 \%$ for orange, $31.5 \%$ for fenugreek , $36.8 \%$ for banana without significant differences. 
Table (3): Effect of treated cowpea seeds with certain plant powders on emerged adults of C. chinensis for three generations at $30 \pm 2{ }^{\circ} \mathrm{C}$ and $75 \pm 5 \mathrm{RH} \%$.

\begin{tabular}{|l|c|c|c|}
\hline \multirow{2}{*}{ Plant powder } & Generation I & Generation II & Generation III \\
\cline { 2 - 4 } & & \multicolumn{3}{|c|}{ emerged adults } & \\
\cline { 2 - 4 } & Mean \pm S.E. & Mean \pm S.E. & Mean \pm S.E. \\
\hline Spearmint & $215.0 \pm 21.85^{\mathrm{d}}$ & $233.3 \pm 24.22^{\mathrm{bc}}$ & $219.7 \pm 21.28^{\mathrm{bc}}$ \\
\hline Lantana & $295.3 \pm 14.20^{\mathrm{bc}}$ & $166.7 \pm 14.82^{\mathrm{c}}$ & $150.0 \pm 23.10^{\mathrm{c}}$ \\
\hline Orange & $198.0 \pm 14.01^{\mathrm{d}}$ & $199.3 \pm 6.55^{\mathrm{bc}}$ & $237.7 \pm 3.65^{\mathrm{bc}}$ \\
\hline Banana & $232.7 \pm 19.73^{\mathrm{cd}}$ & $235.0 \pm 41.93^{\mathrm{b}}$ & $263.3 \pm 15.90^{\mathrm{b}}$ \\
\hline Lupine & $334.7 \pm 20.03^{\mathrm{b}}$ & $258.3 \pm 42.17^{\mathrm{b}}$ & $258.7 \pm 36.32^{\mathrm{b}}$ \\
\hline Fenugreek & $199.7 \pm 25.55^{\mathrm{d}}$ & $200.0 \pm 33.28^{\mathrm{bc}}$ & $210.0 \pm 86.07^{\mathrm{bc}}$ \\
\hline Control & $203.7 \pm 15.90^{\mathrm{cd}}$ & $281.7 \pm 19.70^{\mathrm{b}}$ & $215.0 \pm 27.83^{\mathrm{bc}}$ \\
\hline F & $461.0 \pm 21.70^{\mathrm{a}}$ & $641.7 \pm 17.40^{\mathrm{a}}$ & $471.7 \pm 26.03^{\mathrm{a}}$ \\
\hline L.S.D.5\% & 26.8 & 19.7 & 12.3 \\
\hline
\end{tabular}

Table (4): Protection of treated cowpea seeds with certain plant powders on $C$. chinensis for three generation at $30 \pm 2{ }^{\circ} \mathrm{C}$ and $75 \pm 5 \mathrm{RH} \%$.

\begin{tabular}{|c|c|c|c|c|c|c|}
\hline \multirow[b]{2}{*}{$\begin{array}{l}\text { Leaf } \\
\text { powder }\end{array}$} & \multicolumn{2}{|c|}{ Generation I } & \multicolumn{2}{|c|}{ Generation II } & \multicolumn{2}{|c|}{ Generation III } \\
\hline & $\begin{array}{c}\text { Emerged } \\
\text { females } \\
\%\end{array}$ & $\begin{array}{c}\text { Reality } \\
\text { protection } \\
\%\end{array}$ & $\begin{array}{c}\text { Emerged } \\
\text { females } \\
\%\end{array}$ & $\begin{array}{c}\text { Reality } \\
\text { protection } \\
\%\end{array}$ & $\begin{array}{c}\text { Emerged } \\
\text { females } \\
\%\end{array}$ & $\begin{array}{c}\text { Reality } \\
\text { protection } \\
\%\end{array}$ \\
\hline Spearmint & $30.1 \mathrm{c}$ & 53.4 & $30.4 b$ & 50.5 & $41.9 a$ & 38.2 \\
\hline Lantana & $38.1 b$ & 36.1 & $26.8 b$ & 64.7 & $21.3 d$ & 68.2 \\
\hline Lemon grass & $29.5 \mathrm{c}$ & 59.8 & $30.2 b$ & 57.8 & $34.1 b c$ & 52.3 \\
\hline Orange & $30.7 \mathrm{c}$ & 49.6 & $38.5 a b$ & 50.2 & $33.0 \mathrm{bc}$ & 44.2 \\
\hline Banana & $42.6 \mathrm{a}$ & 25.8 & $36.8 a b$ & 45.3 & $38.9 b c$ & 45.2 \\
\hline Lupine & $33.0 \mathrm{c}$ & 56.8 & $29.9 b$ & 57.6 & $34.7 \mathrm{bc}$ & 55.5 \\
\hline Fenugreek & $29.4 \mathrm{c}$ & 55.9 & $31.5 b$ & 40.3 & $29.3 c$ & 54.4 \\
\hline Control & $39.7 a$ & - & $44.1 \mathrm{a}$ & - & $49.5 \mathrm{a}$ & - \\
\hline $\begin{array}{c}\mathbf{F} \\
\text { L.S.D. } 5 \%\end{array}$ & & & & $\begin{array}{l}3 \\
7\end{array}$ & & $\begin{array}{l}3 \\
2\end{array}$ \\
\hline
\end{tabular}

The third generation showed that the lowest percentage of emerged females was occurred on lantana powder where the percentage of progeny was $21.3 \%, 29.3 \%$ for fenugreek, $33 \%$ for orange, $34.1 \%$ for lemongrass , $34.7 \%$ for lupine, $38.9 \%$ for banana without significant differences, in comparison with $49.5 \%$ in control treatment.

As for the relative protection percentages, results in Table ( 4 ) show that the highest percentages along the three generations were recorded with the 
treatment of lantana powder recording $36.1,64.7$ and $68.2 \%$ for the first , second and third generation, respectively followed by lemon grass and lupine treatments ranging between 52.3 to $59.8 \%$.

From the obtained results it could be classified the tested plant powders as their effectiveness against the cowpea beetle as follow :

1- The first powder was lantana .

2- The second was lupine, fenugreek and lemongrass.

3- The third was spearmint.

4- The last powders included orange and banana powders.

These results are in harmony with those obtained by Rajapakse and Van Emden (1997) who studied the possible use of ten botanicals and four vegetable oils in managing the brucbid beetles of legumes, Callosobruchus chinesis, C. maculatus and $C$. rhodesianus, and found that all four oils tested (corn, groundnut, sunflower and sesame) significantly reduced the oviposition of all three bmchid species at $10 \mathrm{ml} / \mathrm{kg}$ and also significantly reduced the longevity of adults of C. maculutus and C. chinensis at this dose. Tapondjoua et al. (2002) tested powder and essential oil obtained from dry ground leaves of Chenopodium ambrosioides under laboratory conditions for their ability to protect grains from damage by six insect pests, Callosobruchus chinensis, C. maculatus, Acanthoscelides obtectus, Sitophilus granarius, S. zeamais and Prostephanus truncatus. Furthermore, Kawukia et al. (2005) who evaluated the effectiveness of two synthetic insecticides (cypermenthrin and fenitrothion) and three plant-based insecticides (aqueous extracts of tobacco, tagetes and tephrosia) for the control of Callosobruchus spp. , in addition Souza et al. (2011) studied the influence of seed coat on the ability of Callosobruchus maculatus (Coleoptera: Bruchidae F.) larvae to penetrate, develop in and survive on seeds, and reported that the oviposition, larval eclosion and adult emergence of $C$. maculatus were drastically reduced in some seeds and that the time necessary for the surviving larvae to perforate the seed coat increased by up to $100 \%$ in these seeds , also, Nenaah (2014) who tested Powders and essential oils obtained from Achillea biebersteinii, $A$. fragrantissima and Ageratum conyzoides for their insecticidal activity against Sitophilus oryzae, Rhyzopertha dominica and Tribolium castaneum.

\section{REFERENCES}

Abbott, W.S. (1925). A method for computing the effectiveness of an insecticide. (J. Econ. Entomol.; 18 : 265267).

Bato, S.M. and F.F. Sanchez (1972). The biological and chemical control of cowpea weevil Callosobruchus chinensis (F). Philip., Entomol., 2:169 - 182 .

CoStat version 6.400 Copyright (c) 19982008 Cohort Software. 798 Lighthouse Ave. PMB 320, Monterey, CA, 93940, USA.

Haughn,G. and A. Chaudhury (2005). Genetic analysis of seed coat development in Arabidopsis. Trends Plant Sci. 10,472-477

Kawukia, R.S., A. Agonab, P. Nampalaa and E. Adipalaa (2005). A comparison of effectiveness of plant-based and synthetic insecticides in the field management of pod and storage pests of cowpea. Crop Protection 24 (2005) 473-478.

Koura, A., M. EL - Halafawy and T. Shehata (1971). Preference of the cowpea weevil Callosobruchus maculatus to some legume seeds and weight loss due to the insect infestation. Agric, Res . Rev Cairo . $49: 35-40$

Laudnai H., and G.R. Swank ( 1954 ). A laboratory apparatus for determining repellency of pyrethrum when applied to grain . J. Econ . Entomol., 47: 1104 1107.

Leonard, J. E , and L. Ehatman ( 1976 ). Recognition and sexual selection in Drosophila, classification, quantification 
and identification. Science, $193: 693$ 695 .

Mbata, G. IV and O.T. Ekpendu ( 1992 ). The insecticidal action of four botanicals against three storage beetles. In International Symposium on crop protection. Mededelingen van de Facultiet land bouwwetens chappen, Rijksuniversiteit Gent, 57 (3a ): 723 : 733 .

Nenaah, Gomah E. (2014). Bioactivity of powders and essential oils of three Asteraceae plants as post-harvest grain protectants against three major coleopteran pests. Journal of Asia-Pacific Entomology 17 (2014) 701-709.

Oliveira, A. E.A., G. L. Sassaki, M. Lacomini, M. Cunha, K.V.S. Fernandes and J. Xavier-Filho (2001). Isolation and characterization of galactorhamnan polysaccharide from the seed coat of Canavalia ensiformis that is toxic to the cowpea weevil (Callosobruchus maculatus). Entomol. Exp. Appl.101,225231

Phillips, T.W., and J.E., Throne (2010). Biorational approaches to managing stored-product insects,Annu.Rev.Entomol.55,375-397.

Prevetts, P.F. (1961). Field infestation of cowpea ( Vigna Unguiculata) pods by beetles of the families Bruchidae and Curculionidae in Northern Nigeria . Bull . Ent.52:635 -645.

Rajapakse, R. and H. F. Van Emden (1997). Potential of four vegetable oils and ten botanical powders for reducing infestation of cowpeas by Callosobruchus maculatus, $C$. chinesis and $C$. rhodesianus. J. Stored Prod. Res. Vol. 33, No. 1, pp. 59-68, 1997.
Rajendran, S. and V. Sriranjini (2008). Plant products as fumigants for storedproducts insect control. J. Stored Prod.Res.44 (2), 126-135

Ram Singh, Basant Singh and R.A. Verma (2001). Efficacy of different indigenous plant products as grain protectant against Callosobruchus chinensis L . on pea . Indian Journal Entomology , 63 ( 1 ): 179 -181 .

Shivanna, S.S. Lingappa and B .V Patil (1994). Effectiveness of selected plant materials as protestants against pulse beetle Callosobruchus chinensis (Linn) during storage of redgram. Karnataka Journal of Agricultural Sciences 7 ( 3 ): 289-290.

Souza, Amanda J., Patrícia O. Santos, Marcio S.T. Pinto, Tierry T. Wermelinger, Elane S. Ribeiro, Simone C. Souza, Mariana F. Deus, Maria C. Souza, José Xavier-Filho, Kátia V.S. Fernandes, and Antonia Elenir A. Oliveira (2011). Natural seed coats provide protection against penetration by Callosobruchus maculatus (Coleoptera: Bruchidae) larvae. Crop Protection 30 (2011) 651-657.

Tapondjoua, L.A., C. Adlerb, H. Boudaa and D.A. Fontem (2002). Efficacy of powder and essential oil from Chenopodium ambrosioides leaves as post-harvest grain protectants against six-stored product beetles. Journal of Stored Products Research 38 (2002) 395-402. 
كفاعة بعض المساحيق النباتية كواقى لحبوب اللوييا من الاصابة بخنفساء اللويبيا Callosobruchus chinensis L. (Coleoptera : Bruchidae)

\section{باسم محمد الافراوى}

قسم الحشرات الاقتصادية والحيوان الزراعى - كلية الزراعة - جامعة المنوفية

أجريت هذه الدراسة بمعمل البيولوجى بقسم الحشرات الاقتصادية بكلية الزراعة جامعة المنوفية بغرض تقييم الاثر

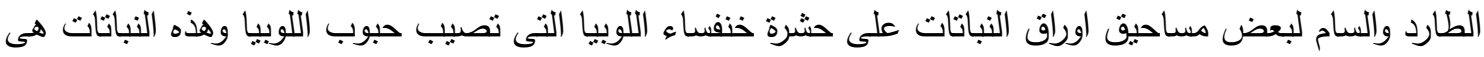
النعناع واللانتانا وحشيشة الليمون والبرتقال والموز والترمس والحلبة ـ وقد اجريت الدراسة لمدة ثلاثة اجيال للحشرة تحت

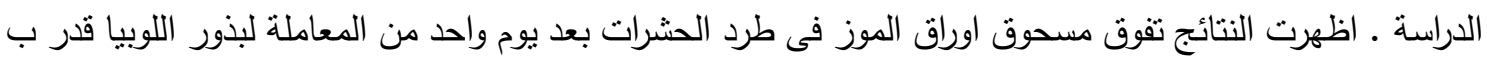

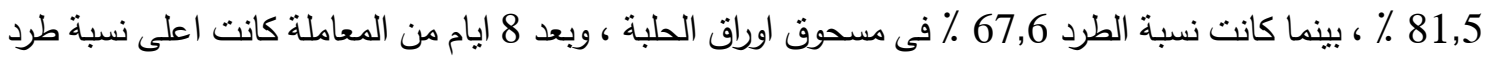

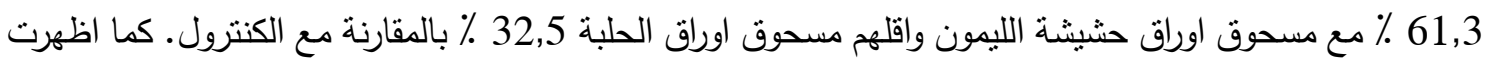

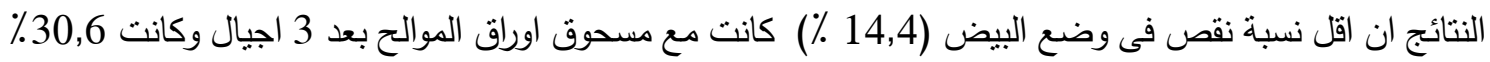
فى كل من الجيل الاول والثانى • وكان اعلى عدد للحشرات الكاملة على مدى ثلاثة اجيال مع مسحوق اوراق الموز

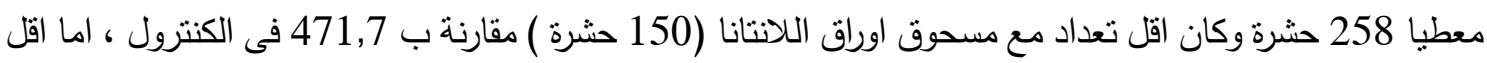
تعداد للحشرات فقد تم تسجيله على مدى الثلاثة اجيال مع معاملة مسحوق اوراق اللانتانا وحشيشة الليمون. كانت اقل

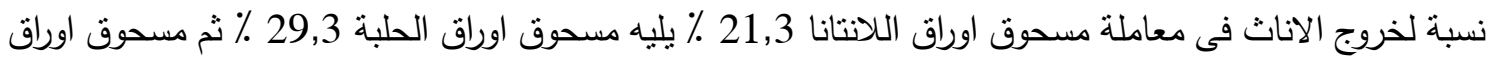

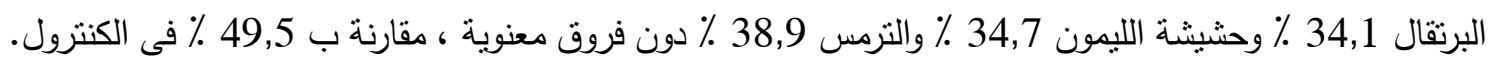

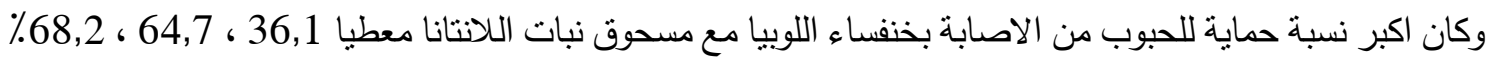

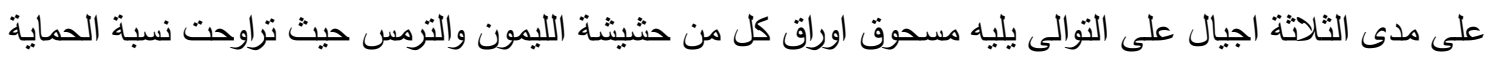

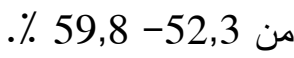

